\title{
ESTÓK József \\ A polgári magyar állam büntetés-végrehajtásának egyenruházata és rangrendszere 1867-1945
}

B örtönügyünk a XVIII. században illetve a XIX. század elején a nyugat-európai országokhoz viszonyítva óriási lemaradásban volt. Magyarországon csak a XIX. század utolsó harmadában jött létre a polgári demokráciák országainak intézményeihez hasonló modern börtönrendszer. A XIX. század kezdetén a lemaradás börtönügyünk minden területén érzékelhető volt. A szabadságvesztés büntetések végrehajtására nem volt egységes elvek alapján müködő intézmény rendszer és a végrehajtásért felelős személyi kör. A szabadságelvonással járó büntetéseket, vármegyénként, de mondhatnánk azt is, hogy településenként is eltérő helyeken, eltérő körülmények között hajtották végre. Ilyen célokat szolgáltak:

- a vármegyék létesítményei, ahol a megyei alispán, tiszti föügyész, várnagy hatáskörébe tartozott a végrehajtás rendjének a meghatározása;

- a városok létesítményei, itt a főbíró, város fiskálisa, porkoláb volt a végrehajtásért felelős személy;

- a pallosjoggal rendelkező uradalmak tömlöcei, ezek müködtetése az uradalmi fiskális, a porkoláb hatáskörébe tartozott;

- a véderő várai, erődítményei, ahol a végrehajtás személyzete döntően a haderő személyi állományának a tagjai közül került ki, e helyeken tartották fogva a hajóvontatásra, a sáncmunkára ítélt rabokat, és a politikai okokból elítélteket. Az elhelyezésüket biztosító objektumoknak a müködtetésében jelentős feladatott látott el a kijelölt katonai parancsnokság. ${ }^{1}$

Nem voltak egységesek a fogvatartási rendszabályok, vármegyénként, sőt esetenként, településenként is eltérö módon szabályozták a börtönök, vagy börtön célra használt létesítmények müködésének rendjét, a személyzet feladatait és kötelezettségeit, öltözetét, felszerelését, a rabok életviszonyait. Zemplén vármegyében a hajdúkkal szemben — az öltözködésüket illetően - elvárás volt, hogy csinosak és tiszták legyenek. Mindenkinek bajuszt kellett viselni. A szolgálatba lépéskor megfelelő öltözetben voltak kötelesek megjelenni. Az ispán rendelkezése szerint minden mundérnak csákónak egyformának kellett lennie, kizárólag magas tetejü szőrkalapot hordhattak, a dolmányt, vagy mentét csak a jobb oldalon viselhették. Rendelkezniük kellett orrba való kendővel. ${ }^{* 2}$

Az első országos jellegű börtönt (fegyintézetet) Mária Terézia fökancellárja gróf ESTERHÁZY Ferenc létesítette 1772-ben a saját birtokán az általa adományozott épületekben a Pozsony melletti Szempcen. A szempci fenyítőház 1772. IX. 4-től fogadta a beutaltakat. Az irányításáért felelős igazgató munkáját az ellenőr és a különböző feladatokat ellátó felügyelők, a tanító, a lelkész, a seborvos, az élelmező segítették. Az örzési feladatokra — a káplárt és a közlegényeket — a pozsonyi katonai főhadparancsnokság állományából rendelték ki. A fenyítőházat 1780-ban Tallósra, majd 1790-ben Szegedre helyezték át, ahol 1832-ig müködött. Müködését a Helytartótanács rendeletek kibocsájtásával szabályozta. ${ }^{3}$

Ebből a korból az egyenruha viselésére kötelezettekkel kapcsolatosan csak nagyon szük körü, felszínes információval rendelkezünk. VAJNA Károly a magyar börtönügy történetét ismertető müvében az éves költségek, kiadások taglalásának soraiban található utalás arra, hogy milyen jellegü öltözékkel rendelkeztek a korabeli börtönörök. ${ }^{4}$ Az őrzési feladatokra a haderőtől vezényelt őrség, a rendszeresített katonai egyenruhát viselte.

A magyar börtönügy fejlődése szempontjából a szempci, tallósi, szegedi fegyintézetek létestésítése, óriási jelentőséggel bírt - függetlenül attól, hogy milyen funkciót láttak el -, mert ez volt az első komoly lépés a büntetés-végrehajtás egységesítésére. ${ }^{5}$

Az 1848-1849-es magyar forradalom és szabadságharc vereségét követően 1852-1860 között a neoabszolutista rendszer részeként a Kárpát-medencében is hatályba léptették az osztrák birodalmi büntető törvénykönyvet. A törvénykönyv központi büntetési neme a szabadságvesztés volt, amit a HABSBURG neoabszolutizmus ,igazságügyi” rendszere előszeretettel alkalmazott is. A szabadság elvonásával járó büntetések végrehajtásához, a megnövekedett elítéltlétszám elhelyezésére azonban nem állt renelkezésre elegendő férőhely.

1854-ben a probléma megoldására a HABSBURG-kormányzat gyors és főként olcsó megoldást keresett. A legkézenfekvőbb módon ezt a célt a meglévő objektumok (várak, erődök és más középületek) börtönökké való átalakításával tudták elérni.

*Glosszárium 
Így vált fegyintézet 1854 és 1858 között a korábban erődítményként működő Lipótvár, Illava és Munkács vára, a nemes ifjak kollégiumának épített váci intézet, illetve Márianosztrán az egykori pálos rendi kolostor. ${ }^{6}$

Hozzájuk sorolandó, az 1857-től Erdélyben — az egyetlen, eleve fegyintézetnek épített — nagyenyedi és a már 1786-tól „,provinciális” börtönként müködő szamosújvári intézet, valamint Horvátországban Lepoglaván a pálos rendi kolostorból és a zágrábi erődből kialakított börtön is.

1852-1860 között a magyarországi állami fegyházak felügyeletét a budai székhelyü Helytartó Tanács, Erdélyben a kolozsvári székhelyü Kormányzóság, Horvátországban pedig a zágrábi székhelyü Helytartó Tanács látta el. Az intézetek felszerelését — így a ruházatot is — eszközeit az állam központilag biztosította. ${ }^{7}$

A büntetések végrehajtására a neoabszolutizmus időszakában az osztrák büntetőtörvénykönyvnek a büntetés-végrehajtásra vonatkozó rendelkezései és más, alacsonyabb szintü birodalmi jogszabályok — többek között az 1850. évi birodalmi belügyminiszter által jóváhagyott börtönszabályzat — voltak érvényben. 1854-ben a HABSBURG-birodalom igazságügyi minisztere rendeletben szabályozta a hatósági fogházak szervezetét és a foglyokkal való bánásmódot. Ebben az időben a hatósági fogházak felügyeletét a bíróságok látták el. ${ }^{8}$

1861-1867 között az állami fegyintézetek változatlanul a Helytartó Tanács felügyelete alatt álltak. A személyzeti és a fontosabb gazdasági ügyek pedig az udvari kancellária hatáskörébe tartoztak. A hatósági fogházak a vármegyei kormányzók, illetve a föispánok, távollétükben pedig az első alispánok felügyelete alatt müködtek. A szervezeti keretekről a Helytartó Tanács 1863-ban külön rendeletben intézkedett. ${ }^{9}$

A ruházatot illetően ebből a korból nem állnak rendelkezésünkre részletes információk. ${ }^{\mathbf{1 0}}$

A Helytartó Tanács a hatósági fogházak szervezeti kereteinek a megállapítása tárgyában kibocsájtott rendeletében szabályozta a várnagy és a felügyelő személyzet feladatait is, valamint az örhajdúk teendöit. ${ }^{11}$

A vonatkozó témájú neoabszolutizmuskori szabályozásokból megállapítható, hogy a személyzet összetételét illetően 1852-1867 között még mindig nagyon kaotikus viszonyok uralkodtak a börtönökben. Az irányító apparátus tagjai hivatalnokok, a belső szolgálatot ellátók, a munkát irányítók pedig a fegyörök körébe tartoztak. Az örzési feladatokat teljesítők csoportjában megtalálhatók voltak a fegyőrök, a katonák, a hajdúk, akiknek az öltözete a szervezeti hovatartozásuknak megfelelő volt.

A kiegyezést követően a nyugállományba vonult fegyintézeti igazgatók beosztását több helyen az 1848-1849-es magyar forradalom és szabadságharc veterán honvédtisztjeivel töltötték be. ${ }^{12}$

A börtönügy a kiegyezést követően az igazságügyi tárca irányítása és felügyelete alá került. Az 1870. évi igazságügyminiszteri rendeletben szabályozták a polgári magyar állam időszakában első ízben a fegyőrök öltözetét. ${ }^{13}$

A magyar börtönügy személyi állományával kapcsolatos intézkedések nem választhatók el a börtönügy egészétől, illetve a polgári magyar állam kiépítésének és fejlesztésének a folyamatától.

(A kiegyezéskor nyilvánvalóan nem lehetett átvenni az 1848-1849-es magyar forradalmat és szabadságharcot cári segédlettel vérbe fojtó HABSBURG-hatalom neoabszolutikus rendszerét, mivel annak a lényegéhez tartozott a magyar hazafiak üldözése. Ez a hatalom a magyar nemzet felszámolására törekedett, az eszköze pedig a neoabszolutista rendszer volt. A HABSBURG-neoabszolutizmus politikájának elvi alapjai Félix Ludwig Johann Fürst zu SCHWARZENBERG [Böchmisch-Krumau 1800. X. 2. Bécs 1852. IV. 5.] hercegnek, csehországi németajkú arisztokratának Ferencz József miniszterelnökének nevéhez kapcsolódik, mely politikát miniszterelnökként [1848 novemberétöl haláláig] a gyakorlatban is igyekezett megvalósitani. Az úgynevezett jogeljátszási elmélet [Verwirkungstheorie] szerint a magyar nemzetnek voltak ugyan jogai, azokat azonban elvesztette azáltal, hogy a törvényes uralkodója ellen fellázadt. Ezen álnok okfejtés alapján - melyet DEÁK Ferenc a kiegyezés elökészitése kapcsán cáfolt — szüntették meg a magyar államot és az ország területét tartományokra szabdalva beolvasztották a HABSBURG-császárságba, hivatalos nyelvvé pedig a németet tették. A neoabszolutista rendszer nem ellenezte a polgári fejlödést, hanem támogatta azt. A polgári fejlödést azonban a magyar nemzet megszüntetésére szerette volna felhasználni. Nem egyszerüen az 1848-1849-es magyar forradalom és szabadságharc miatti bosszúról volt azonban szó, hanem arról, hogy a HABSBURG-birodalom valamennyi lakójának az elnémetesitésével szerettek volna olyan németajkú tömeget létrehozni, amelyre támaszkodva HABSBURG vezetéssel kivánták volna megvalósitani a nagynémet egységet. A porosz vezetéssel létrehozott kisnémet egység, a Solferinó-i [1859. VI. 24.] és a Königrätz-i [1866. VII. 3.] vereségek, valamint a magyar nemzet passzív rezisztenciája azonban arra kényszeritette a HABSBURGokat, hogy kiegyezzenek a magyarsággal. ${ }^{14}$ a szerk.) 
A kiegyezési törvényt a magyar és az osztrák országgyülés is becikkelyezte. Ez mindkét társország sarkalatos törvénye volt, hiszen meghatározta és elhatárolta a közös ügyeket és azok intézésének a szabályait, illetve az uralkodói felségjogokat és a két társország jogkörét. ${ }^{15}$

A kiegyezés utáni magyar kormányok tehát — a polgári magyar állam megteremtésének a részeként - hozzákezdtek a polgári magyar börtönügy kiépítéséhez. Ennek során kettős tendencia érvényesült. Egyrészt meríteni kívántak a fejlett nyugat-európai börtönügy tapasztalataiból, másrészt pedig még a látszatát is el szerették volna kerülni annak, hogy a közutálat tárgyát képező neoabszolutista rendszertől bármit is átvesz a magyar állam. Így a magyar polgári börtönügy tekintetében nem az osztrák, hanem a nyugat-európai tapasztalatokat igyekeztek hasznosítani. ${ }^{16}$

A Magyar Királyságban a kiegyezést követően Európa legkorszerübb börtönügyi jogszabályrendszerét alakították ki az igazságügyi tárca vezetésével. Mivel azonban a magyar börtönügy elavultsága komplex volt, ezért nem csupán a vonatkozó jogszabályokat, hanem a tárgyi és a személyi feltételrendszert is fejleszteni kellett. Elkezdődött a magyar büntetés-végrehajtási rendszer épületbázisának a fejlesztése, az épületek terén a dualizmus alatt szép eredményeket értünk el. A trianoni békediktátum azonban visszavetette a magyar börtönügy elhelyezési feltételrendszerét, melynek a következményeit a XXI. század elejéig sem sikerült kiheverni. ${ }^{17}$

A jogi és tárgyi feltételrendszer mellett létre kellett hozni a személyi feltételrendszert is. ${ }^{18}$

A polgári magyar állam időszakában az állami alkalmazottak humán viszonyrendszerét egységesen szabályozták függetlenül attól, hogy az állam által foglalkoztatottak a magyar állam mely alrendszerében tevékenykedtek. Az állami alkalmazottak ellátásának az volt az alapelve, hogy az állam kötelessége alkalmazottai számára a társadalmi állásukhoz méltó életvitelhez szükséges feltételek biztosítása. Ez a feltételrendszer magába foglalta a:

- fizetéseket;

- a lakhatás biztosítását;

- egyenruhás szervezetek esetében az -öltözéket, illetve annak az előállítási költségeit;

- az orvosi ellátást;

- a nyugdíjjogosultságot.

Ez a rendszer kezdetben a központi államhatalomnak közvetlenül alárendelt szervezetekben tevékenykedőkre terjedt ki. A két világháború között azonban fokozatosan kiterjesztették az önkormányzati alkalmazottakra is. ${ }^{19}$

Az állami alkalmazottak humán rendszerének az alapját a képzettségek alkották. Az érettségihez, vagy annál magasabb iskolai végzettséghez kötött beosztásokat XI fizetési osztályba sorolták, melyet a gyakornokok fizetési osztálya egészített ki. Az iskolai végzettségi szintekhez — érettségi, diploma fizetési osztályok tartoztak. A magasabb fizetési osztályokba az alacsonyabb fizetési osztályból az elöírt idő leteltével léphettek az állami alkalmazottak. Emellett a fizetési osztályokon belül megkülönböztettek fizetési fokozatokat is azok számára, akik — képesítési hiányosságok, vagy állásüresedés híján - nem voltak előléptethetők a magasabb fizetési osztályokba. Öket bizonyos idő elteltével a fizetési osztályon belüli magasabb fizetési fokozatba sorolták. Az állami iskolai végzettség a beosztások betöltésének csupán az előfeltétele volt. Megfelelő iskolai végzettség birtokában a szakterület gyakorlati tapasztalatait felölelő szakmai képzésben is részesültek a leendő állami alkalmazottak. Ennek a sikeres elvégzése nyomán voltak kinevezhetők. Ezt a rendszert képezték le alacsonyabb szintre a rendvédelmi testületek legénységi állományára vonatkozóan. ${ }^{20}$

Az előírt szellemi kvalifikáció mellett a kinevezés feltétele volt továbbá a megfelelő egészségi állapot, a léha életmódtól való mentesség, a bünügyileg fertőzetlen környezetből való származás. Egyenruhás szervezetek esetében mindez kiegészült még az ép testalkattal is, mivel egyenruhát csak ép testalkatú ember hordhatott.

A tisztviselői - egyenruhás szervezet esetében a tiszti — kar tagjainak a véglegesítését a gyakornoki idő letöltése előzte meg. A fegyveres szervezetek legénységi állományánál ezen időt próbaidőnek nevezték. A próbaidő, illetve a gyakornoki idő hossza a polgári magyar állam időszakában fokozatosan gyarapodott, végül a két világháború között elérte a három évet. A tisztviselői kar fegyveres testületeknél a tiszti kar — tagjai a gyakornoki idő alatt tették le az elméleti és gyakorlati közigazgatási szakvizsgájukat és szereztek gyakorlati tapasztalatokat a leendő szakterületükön. A legénység körébe tartozók pedig a próbaidő alatt végezték el a leendö hivatásuk gyakorlásához szükséges elméleti ismereteket nyújtó tanfolyamot és szereztek gyakorlati ismereteket a betöltendő munkakörük ellátásához. ${ }^{21}$

Az állami alkalmazottak számára az államnak lakhatást is biztosítania kellett. A nőtlen legénység esetében ez laktanyai elhelyezést, míg a nőtlen tisztek esetében garzon-lakás bérlését jelentette. Min- 
den állami alkalmazott számára — függetlenül attól, hogy az állam mely alrendszerében tevékenykedett — járt a beosztás szintjétől és a család nagyságától függő méretủ és komfortfokozatú lakás. Ezen lakás bérleti díját a nyugdíjazása után is a haláláig az állam fizette, sőt az özvegyének is mindaddig, amíg újra férjhez nem ment. ${ }^{22}$

Az állami alkalmazottak ellátási rendszerének sarkalatos eleme volt a nyugdíj. Az állami alkalmazottak - ha elérték a nyugdíjkorhatárt, ami 65 év volt — nyugdíjjogosulttá váltak. 10 évi szolgálati idő után — amibe beletartozott a próbaidő, illetve a gyakornoki idő is — a fizetés $40 \%$-a alkotta a nyugdíjat, ezt követően minden letöltött szolgálati év $2 \%$-kal növelte a nyugdíj mértékét. 40 éves szolgálati idővel az állami alkalmazottak fizetésük $100 \%$-val mehettek nyugdíjba. 65 éves koruk után, vagy 40 éves szolgálati időn túl viszont nem maradhattak szolgálatban, mivel senkinek sem lehetett a nyugdíja magasabb mint a fizetése. Az állami alkalmazottak - és közvetlen, velük egy háztartásban élő családtagjaik számára — fizetésük néhány százalékos befizetése nyomán térítésmentes orvosi ellátás és kedvezményes gyógyszerellátás is járt. ${ }^{23}$

Az egyenruhás szervezetek tagjainak ruhaellátás járt. A tisztek esetében ez évente a részükre kifizetett állandó összeget jelentett, amely a szabóknál csináltatott egyenruha árát volt hivatott fedezni. A legénységi állomány tagjai számára az egyenruhát általában természetbeni juttatás formájában biztosították.

Az állami alkalmazottak ellátási rendszere tehát egységes volt, bár az egyes szakterületek közötti nehézségi, veszélyességi különbségeket pótlék formájában honorálták. Így kaptak például a fegyveres szervezetek tagjai testületi pótlékot.

(Az egységes ellátási rendszer a hazai hagyományokat tükrözö rang-és címrendszerrel párosult. A katonailag szervezett fegyveres örtestületek tagjai Magyar Királyi Folyamörség (1921-1939) kivételével a szárazföldi haderönem rendfokozati rendszerének a rangjait viselték, mig a polgári fegyveres örtestületek személyi állománya a testületi rendfokozati rendszer rangjait viselte. A katonai rangokat hatágú csillaggal, míg az egyenruha viselésére jogosult tisztviselők rangjait rozettával, a polgári fegyveres örtestületek személyi állományának a rangjait pedig úgynevezett csillagrózsácskával jelölték. ${ }^{24}$

\section{[I.sz. melléklet]}

A magyar büntetés-végrehajtás hivatalnokai esetében a kitüntetési jelvényeket, a fegyörök esetében a rangjelvényeket a parolin helyezték el, ugyanúgy, mint a többi fegyveres szervezet, illetve a haderö tagjainál, vagy az egyenruha viselésére jogosult hivatalnokoknál. A parolin azonban a csillagok, csillagrózsácskák, rozetták alatt és a fegyvernemi, illetve testületi szín között paszomány volt található. Háromféle paszományminta létezett a katonaállományúaknak, a hivatalnokoknak és a katonai hivatalnokoknak eltérö paszománymintázata volt. [II.sz. melléklet]

A csillag, csillagrózsácska, illetve rozetta szine [arany, ezüst] és a paszomány színe [arany, ezüst], továbbá a paszomány mintázata ] háromféle paszományminta] együttesen és egyformán határozta meg viselöjének az állami hierarchiában betöltött szintjét függetlenül attól, hogy az állam mely alrendszerében tevékenykedett és hogy mely rangrendszer [katonai, fegyveres testületi, vagy hivatalnoki] rangját viselte. Ennek az egységes állami rendfokozati rendszernek képezte a részét a büntetésvégrehajtási rangrendszer ${ }^{\mathbf{2 5}}$

A rendszer tehát egyértelmü, logikus, jól kezelhetö volt. A tüzoltó szervezetek - egységes és centralizált tüzoltó testület a polgári magyar állam idöszakában nem volt a Magyar Királyságban - és a fegyöri testület esetében a csillagrózsácska használatát azonban a társ rendvédelmi testületekhez viszonyitva későn, a két világháború közötti idöszakban vezették be. A szerk.)

Katonailag szervezett fegyveres örtestületnek azokat a szervezeteket nevezték, amelyekben az alá- és fölérendeltségi viszonyok katonaiak voltak, a személyi állomány tagjai pedig katonai rendfokozatot viseltek. Öket a katonákra vonatkozó általános jogosultságok megillették, illetve kötelezettségek terhelték. E testületek tagjai személyükben katonának minősültek, ezért a honvédelmi tárca felügyelete alá tartoztak függetlenül attól, hogy a testületük — ahol szolgálatot teljesítettek — irányítását a magyar állam mely tárcája végezte. Ezzel szemben a polgári fegyveres őrtestületekben a személyi állomány alá- és fölérendeltségi viszonyai hivatalnokiak voltak. A személyi állomány tagjai pedig nem katonai, hanem a testületi rendfokozati rendszer rangjait viselték. E testületek tagjaira a katonákra általában érvényes jogosultságok és kötelezettségek nem vonatkoztak. A személyi állomány tagjai pedig nem a honvédelmi tárcához, hanem a testület felügyeletét ellátó minisztérium kompetenciájába tartoztak. ${ }^{26}$

A magyar büntetés-végrehajtási szervezet polgári fegyveres örtestület volt. Ez azonban nem jelentette azt, hogy a testületen belül — a hivatalnoki alá- és fölérendeltségi viszonyrendszer keretei között — ne uralkodott volna szigorú fegyelem. Akár katonailag szervezett őrtestület, akár polgári fegyveres őrtestület esetében a felvételi eljárás részét képezte annak a megállapítása is, hogy a jelent- 
kező katonaviselt volt-é. Katonai szolgálat hiányában a jelentkezők általában nem kerülhettek be a testület tagjai közé. Ebből a körülményből fakadóan pedig mindkét rendvédelmi fegyveres örtestület típus körében összehasonlíthatatlanul eredményesebben lehetett kialakítani és fenntartani a szigorú fegyelmet, mintha a testületbe lépéskor fordítottak volna gondot az általános alaki és viselkedési szabályok oktatására.

A polgári magyar állam időszakában a büntetés-végrehajtási szervezet tehát polgári fegyveres őrtestületként müködött. Ebből fakadóan a személyi állománya a testületi rangrendszer rangjait viselte, amelyeket — a szárazföldi haderőnem rangrendszerének a mintájára — általában a zubbony gallérján helyeztek el hármas tagolásban. A rangok jelölésére pedig — a társ polgári fegyveres őrtestületekkel megegyezően - csillagrózsácskát használtak tisztek (tisztviselők) esetében arany, altisztek esetében ezüst, a legénység esetében pedig csont színben. E rangrendszer egyes rangjait csíkok használata is kiegészítette. Általában minden rendvédelmi testület — akár katonailag szervezett őrtestület, vagy polgári fegyveres örtestület - testületi színnel is rendelkezett. E testületi szín volt a paroli ${ }^{*}$ alapja, amelyen a rendfokozati jelöléseket elhelyezték. ${ }^{27}$

Ebbe az országos rendszerbe illeszkedett a korabeli büntetés-végrehajtási testület személyi állománya a testületi tagok képesítési követelményrendszere és a személyi állomány társadalmi állásához méltó életvitelhez szükséges feltételek biztosítása által, melynek a részét képezte a testületi egyenruha és rangrendszer is. A XXI. századból visszatekintve ez bizonyára nem jelent különösebb kvalifikációs színvonalat. Figyelembe kell azonban venni, hogy — az önkormányzati felügyelet alatt álló — magyar rendőrségek személyi állományának mintegy $20 \%$-a ekkor még írástudatlan volt. A központi államhatalomnak közvetlenül alárendelet fegyveres testületek legénységi személyi állományával szemben azonban felvételi követelmény volt a négy elemi iskolai végzettség.

Az igazságügyi tárca börtönüggyel kapcsolatos egyik első intézkedései közzé sorolható a fegyőrök és a fegyencek ruházatának meghatározása, egységesítése. Az igazságügyminiszter a börtönökben szolgálati feladatokat ellátók felszerelését, ruházatát kitüntetési jelvényeit, illetve rangjelvényeit ${ }^{*}$ külön rendelettel állománycsoportonként, szabályozta.

- I. állománycsoportba tartoztak az intézetekben dolgozó hivatalnokok;

- II. állománycsoportba tartozott az intézetek őrszemélyzete.

A kiegyezés után megalakult igazságügyi kormányzat általános elvként rögzítette, hogy: „, A fegyörök a katonaihoz hasonló fegyelem alatt álltak, fegyveresen szolgálnak, egyenruhát viselnek, de azért polgári jellegüket megtartják.",28

Az igazságügyminiszter 1895. évi rendeletében az egyenruhák és a rangfokozatok viselésével kapcsolatos általános célként fogalmazta meg, hogy:

- a tisztviselő szolgálat teljesítése közben felismerhető legyen;

- az egyenruha viselésére kötelezettek tekintélyük növelése és a személyes védelmük, érdekében kötelesek voltak kardot viselni.

A fegyőrök egyenruhái kivitelre a honvédség, vagy budapesti rendőrség egyenruháinak a mintáját követték, több ruházati termék pedig azok színét is átvette. ${ }^{29}$

Az egyes rangfokozatok elérését, viselését befolyásoló tényezők voltak a képzettség által meghatározott állománycsoportba való tartozás (tisztviselő, őrszemélyzet), illetve a fizetési osztályba sorolás. Mindenki tartozott valamilyen fizetési osztályba, a tisztviselők az egységes állami ,fizetési osztályok közül azon osztályba, ahová a végzettségük szerint őket besorolták, a legénység tagjai pedig — az egységes állami fizetési osztályok mintájára kialakított — testületi fizetési osztályok egyikébe. A fizetés mértékét emellett befolyásolta a szolgálati hely is, mivel a szigorúbb, nagyobb befogadóképességü büntetőintézeteknél szolgálatot teljesítők fizetése kedvezőbb volt. ${ }^{30}$

Az igazságügyminiszter az 1891. évi rendeletével részletesen szabályozta a hivatalnokok öltözetét és rangfokozati rendszerét. ${ }^{31}$

A büntetőintézeti hivatalnokok és fegyőrök öltözetének szabályozására vonatkozó 1891. és 1895. évi igazságügyminiszteri rendeletben foglaltakat a fogházfelügyelőkre is alkalmazni kellett. ${ }^{32}$

Az 1891. évi igazságügyminiszteri rendelet szerint az országos büntető-intézeteknél alkalmazott hivatalnokok egyenruhája kétféle volt: díszöltöny és háziöltöny.

A díszöltönyhöz tartozott: a kalap, az attila, a díszpantalló és a kesztyü.

\footnotetext{
* Glosszárium
} 
A házi öltöny részét képezték: a sapka, a zubbony, a szürke pantalló, vagy csizmanadrág, kard, nyakravaló, "cipő vagy csizma.

Mindkét öltözetet a szükséghez mérten kiegészítette: a köpeny és a csuklya.

A kalap a fövárosi rendőrök és az országos büntető intézeti örök által használtakéhoz hasonló alakban, finom fekete nemezből* kereken domború tetővel és ezzel egy darabban gyártott lejtős karimával készült.

A gömb alakú fejtető legnagyobb magassága 13 centiméter volt, a belsejét pedig finoman bélelték.

A kereken lejtős karima 5,5 centiméter szélességű volt, melyet köröskörül 2 centiméter széles három egyenként egy-egy milliméter széles ibolyaszín selyem csíkkal átszőtt aranyszalaggal szegélyeztek. ${ }^{33} \mathrm{Az}$ aranyszalag végei a kalap balról viselendő oldalának közepén egy 4 centiméter magas és 3 centiméter széles lapos aranyozott érc boglár ${ }^{*}$ alatt végződtek. A boglár két egymás felé hajló lombág között a magyar címer fölött elhelyezett koronából állt.

A kalapot a karima fölött 2 centiméter széles, három egyenként egy-egy milliméter széles ibolyaszínü csíkkal átszőtt aranyszalaggal övezték.

A verítékbőr ${ }^{*}$ szattyánszerü* juhbőrből készült.

A boglár mögé tüztek egy mintegy 30 centiméter hosszú és a fővárosi rendőrök által hordottal teljesen azonos fehér lószőr-forgó. (III.sz. melléklet)

Az attila a honvéd tisztekéhez hasonló szabással, finom sötétkék posztóból készült 5 milliméter vastagságú aranyzsinórokkal díszítve, melyekbe 1,5 centiméternyi távolságokban egy-egy szál 0,5 milliméter szélességü ibolyaszín selyemcsíkot szőttek.

A baloldali mellrész bélésében a hónalj magasságában egy belső zseb, ezen kívül az alj előrészein egy darab 13 centiméternyi nyílású ferde külső zseb volt kettős zsinórral szegélyezve, melynek minden vége karikát képezett.

Az attila álló gallérral készült és fehér merinóval ${ }^{*}$ bélelték. Az attila a felső derékból, az aljból, az ujjakból és a gallérból állt. A felső derék két mellrészből állt, melyeket a két oldalrésszel és az egész darabból szabott hátrésszel varrtak össze. (IV.sz. melléklet)

A mellrészeket — a gallértól a deréktermetig — öt gomblyukkal, illetőleg öt darab aranyozott fémgombbal látták el. A gombokat egymástól egyenlő távolságban a gallér záródásától 2 centiméternyire az előszéltől pedig 5,5 centiméternyire varrták fel. Az attilán mellzsinórok nem voltak.

A szélső kapocspárok között még négy pár hím- és nőkapocs úgy volt - a mellzsinór hézagok közepén - felvarrva, hogy azok a szegélyzsinór külső szélétől 2 centiméternyire estek. (IV.sz. melléklet)

A két hátvarrást derékig arany zsinórral borították, amely fönt mindkét oldalon hármas, lent a deréknál pedig egyes karikákat képezett.

Az attila alja két darab előrészből és egy darab hátrészből állt, melyet úgy állítottak össze, hogy az attila alsó szélén az ellenráncok 5 centiméter szélesen a felső végeik 1,5 centiméteres átmérővel gömbölyödtek, a varrás vonalaiban pedig 4 centiméternyire estek egymástól. (IV.sz. melléklet)

Az ellenráncok felső gömbölyítvényeire aranyzsinórból karikákat varrtak, amelyek a hátzsinór folytatásával egyesülve, ferde irányú vitézkötéseket képeztek. Ennek alsó csúcsa az attila alsó zsinórszegélyéig ért és az ellenráncoktól 12 centiméternyire esett.

Az ujjak mindegyikét egy darabból szabták, a varrást pedig befelé fordították. Az ujj alsó végétől 11 centiméternyire aranyzsinór díszítés helyeztek el, amely az ujj szélességének belső harmadában vitézkötést ${ }^{*}$ alkotott.

A 9 centiméter hosszú parolival ellátott gallér végeit 1,3 centiméternyi átmérővel gömbölyítették oly módon, hogy a begombolt attilánál háromszögü kivágás képződjön, amelynek a felső nyílásának 2,6 centiméternyi volt. (A magyar börtön-történeti kutatások jelenlegi állása szerint nem került a felszínre olyan dokumentum, amelyből konkrétan kideríthető volna, hogy a magyar büntetés-végrehajtási szervezet számára miért a lila színt határozták meg. Valószínüsíteni lehet azonban, hogy a keresztény kultúrkörben a lila színhez társított gondolatok képezhették az alapját a testületi szín kijelölésének. A lilára ugyanis a keresztények úgy tekintenek, mint a bünbánat színére. Jézus szenvedését lila színben

\footnotetext{
* Glosszárium
} 
ábrázolták, illetve a XIII. század óta advent és nagyböjt alatt is — mivel ez a bünbánat ideje — általában a gyászmiséken lila színt használ az egyház.)

A kitüntetési jeleket a módosított öltözködési szabályzat szerint az egyes állásoknak és fizetési osztályoknak egymástól való megkülönböztethetősége miatt határozták meg. A rangfokozatoknak az egyes állások és fizetési osztályok egymástól való megkülönböztetését is kifejezésre kellett juttatniuk. Ezért az egyenruha zubbony, illetve az attila gallérját kitüntetési jelekkel látták el.

Az igazgatók attilájának gallérját köröskörül három centiméter széles aranypaszománnyal borították.

A paszományon a gallér mindkét végén:

- az V. fizetési osztályba tartozó igazgató rangjelzésül az egyenruha gallérjára varrott három centiméter széles aranyszínű paszományon a gallér mindkét végén egy ezüst csillagrózsácskát ${ }^{*}$ ezen kívül a bal váll felett 5 milliméter széles meggyszínű selyemmel átszőtt aranyzsinórból készült vállfonatot és a nadrágon ibolyaszínü 4 centiméter széles függőlegesen menő sávot viseltek; ${ }^{34}$

- a VI. és a VII. fizetési osztályba sorolt igazgatók az egyenruha gallérjának csukaszürke hajtókájára felvarrott ezüst paszományon a gallér mindkét végén a VI. fizetési osztályban három háromszög alakban, a VII. fizetési osztályban két arany rózsácskát ferdén felvarrva viseltek, ezen kívül a bal váll felett 5 milliméter széles meggyszínű selyemmel átszőtt aranyzsinórból készült vállfonatot hordtak. ${ }^{35}$

- a VIII. fizetési osztályba sorozott igazgatók egy-egy ezüst csillagrózsácskát viseltek, az ezüst csillagrózsácskákat aranylemezkékből képzett kereszttel szőtték át; ${ }^{36}$

- a IX. fizetési osztályba sorozott igazgatók gallérjának aranypaszományára csillagrózsácska, vagy egyéb jelvény nem került. ${ }^{37}$

A VIII., VII. és a VI. fizetési osztályba sorolt tisztviselők egyenruha gallérjának csukaszürke hajtókájára felvarrott ezüst paszományán a gallér mindkét végén a VIII. fizetési osztályban egy, a VII. két a VI. fizetési osztályban három arany rózsácskát viseltek.

A IX. fizetési osztályba sorolt ügynökök és ugyanebbe a fizetési osztályba sorolt ellenörök a gallér mindkét végén az ibolyaszínű parolira háromszögbe felvarrva három-három arany rózsácskát viseltek, az arany rózsácskákat ezüstlemezkékből képzett kereszttel szőtték át.

A X. fizetési osztályba sorolt ellenőrök és gondnokok a gallér mindkét végén az ibolyaszínü parolira ferdén egymás fölé fölvarrott két-két ezüstlemezkékből képzett kereszttel átszőtt arany csillarózsácskát viseltek.

A XI. fizetési osztályba sorozott tiszti írnokok a gallér mindkét végén az ibolyaszínủ parolira felvarrva egy-egy ezüstlemezkékből képzett kereszttel átszőtt arany csillagrózsácskát viseltek. ${ }^{38}$

Az intézeti orvosok a IX. fizetési osztályban három-három, a X. fizetési osztályban két-két az ibolyaszínű parolira a fenti módon felvarrt ezüst csillagrózsácskát viseltek, melyeket aranylemezkékből képzett kereszttel szőttek át. ${ }^{39}$

A XI. fizetési osztályba sorozott intézeti tanítók az ibolyaszínủ parolira felvarrt egy-egy ezüst csillagrózsácskát viseltek, amelyeket aranylemezkékből képzett kereszttel szőtték át. ${ }^{40}$

Minden tisztviselő csakis azokat a kitüntetési jeleket viselhette, amelyekre az öltözködési szabályzat szerint állása és fizetési osztályba tartozása alapján joga volt, azok a tisztviselők azonban, akik az 1893/IV.tc. életbelépte előtt magasabb rangosztályba tartoztak, mint amelybe a törvény állásukat később besorolta, addig, amíg az állást betöltötték az előbbi magasabb fizetési osztálynak megfelelő kitüntetési jeleket viselhették. ${ }^{41}$

A fogházfelügyelőket — a budapestieket kivéve — a XI. fizetési osztályba sorolták és az ugyanabba a fizetési osztályba sorolt tiszti írnokok kitüntetési jelvényeit viselték.

A budapesti három fogházfelügyelő, akiket a X. fizetési osztályba soroltak, az ugyanabba a fizetési osztályba sorolt ellenőrök és gondnokok kitüntetési jelvényeit viselhették. ${ }^{42}$

A díszpantalló az attiláéhoz hasonló sötétkék finom posztóból készült, két combrészből (nadrágszárból) állt, amelyeket egy-egy előrészből és hátrészből varrták össze. Az elő- és hátrészek külső varratában ibolyaszínú posztóból 1,5 milliméter széles szegélyt helyeztek el.

A kesztyük mosható fehér börből készültek.

A sapka a honvéd tisztekéhez hasonló alakban, fehér sima posztóból készült, szemernyővel, állszíjjal, melyet hurkos rózsával láttak el.

A országos büntetőintézeteknél és a bírósági fogházaknál alkalmazott tisztviselök öltözködési szabályzata módosult, nevezetesen a házi öltönyhöz tartozó fehér sapka helyett a sima fekete posztóból készített sapkát rendszeresítették számukra.

A sapka közepén elöl 9 centiméter, hátul pedig 12 centiméter magasságú, négy oldalrészből és a fejbőségnek megfelelő tojásdad tetőből állt. 
A 4,5 centiméter szélességű szemernyő feketére lakkozott bőrből készült, a külső szélén beszegve, mérsékelten lefelé hajlítva, a sapka alsó szélét pedig köröskörül ibolyaszínnel átszőtt aranyzsinórral volt borították.

A sapka elején, közepén hasonló arany zsinórból egy kis aranyozott gombbal fölszerelt hurkot alakítottak ki, mely fölé aranyrózsát helyeztek.

A 3 centiméter átmérőjü sapkarózsa 2 milliméter vastagságú, szorosan záródó fényes aranysodralékból állt. Ennek közepében ibolyaszínü bársonymező volt, amelyben halvány aranyból hímzett magyar korona volt látható.

A 2,5 centiméter szélességü állszíjat feketére lakkozott bőrből készítették és aranyozott bürü csattal* látták el, melyet mindkét végén két kis aranyozott gombbal, a szemernyő végei fölött a sapkafejhez erösítettek. ${ }^{43}$

A zubbony finom sötétkék posztóból korc nélkül készült, 5 darab aranyozott rézgombbal, melyet állógallérral láttak el. A gallér felső és alsó szélét az attilánál alkalmazotthoz hasonló aranyzsinórral szegélyeztek, amely a gallér hátsó közepén 1,5 centiméter átmérőjü felálló karikát képezett. A gallér elejére a két zsinór között 9 centiméter hosszú ibolyaszínủ hajtókát varrtak, melyen az attilánál leírt kitüntetési jeleket (rangokat) úgy helyezték el, hogy a hajtóka vége 1 centiméternyire látható maradt.

A zubbonyon az igazgatók is csak 3 centiméter széles 8 centiméter hosszú aranypaszományt viseltek, úgy, hogy az ibolyaszín hajtókából 1 centiméter kilátszott. A zubbony ujjain nem volt karzsinór, aranypaszomány vagy sujtás. A zubbony mindkét oldalán — úgy a mell, mint a csípők táján egyegy összesen négy — sötétkék bélésvászonból készített zsebet képeztek ki, amelyeket zsebfödelekkel láttak el.

Az ujjak mindegyike alsó varrással összekapcsolt darabból álltt. ${ }^{44}$

A fegyőrök számára rendszeresített szürke pantalló és csizmanadrág a vizsgált időszak haderőinél az Osztrák-Magyar Monarchia haderejénél is általában házi egyenruhaként volt viselhető.

A szablya megegyezett a földmüvelési tárca állatorvosainak díszöltözékéhez rendszeresített szabláyval. A szablya a pengéből, a fogantyúból és a hüvelyből állt.

A rugonyacél penge hosszúsága 79 centiméter, a fogantyúnál 2 centiméter szélességủ volt, melyet a hegyétől 20 centiméter hosszúságban kétélüvé formáltak, innen pedig a markolat előtt 2 centiméterig egy éllel rendelkezett. Mindkét lapján homorágat alakítottak ki. A fogantyú azonos volt a gyalogtiszti kardokéval, fekete, rovátkás, a markolatkereszt, a kupak és markolat-karika aranyozott sárga fémböl készültek. A markolat-karika négy részre ágazott, melyből három ág kifelé domború hajlítás által kosarat képezett. A kardhüvelyt a penge alakja és méretei szerint formált acélbádogból gyártották, melyet feketére lakkozott bőrrel vontak be és aranyozott fémből készült két darab hordpánttal és ugyan olyan anyagú csúsztatósaruval láttak el. A felső hordpánt egyúttal szájkarika* gyanánt is szolgált. A 2,5 centiméter szélességü, alul hegyes hordszijakat, külső oldalukon aranypaszománnyal vonták be és a hosszközepükön 2 milliméter szélességü ibolyaszínű selyemcsíkkal szőtték át. A kardkötőt úgy kellett a derékszíjjal az attila, vagy zubbony alatt a derékra kötni, hogy az első hordszíj a bal felső́comb mentén lógjon le, és a kard szúrlapja az attila alsó szélével egy vonalba essen, a kardhüvely alsó vége pedig a földet ne érintse. ${ }^{45}$ (V. sz. melléklet)

A nyakravaló fekete selyem vagy gyapjúszövetből, a honvédtisztekéhez hasonló formában készült, fehér nyakszegéllyel ellátva.

Félszáru csizma vagy a rugony-bevarratú* cipő nem lakkozott bőrből készült, mindkettő feketített és simafejü. A csizmát szolgálatban a helyi viszonyokhoz igazodva hordták, fekete nem fényezett börből készült, kanyaros szegélyü, egyszerü bőrrózsával ellátott szára volt, a gyalogos tisztekéhez hasonló alakban. $^{46}$

A köpeny - szintén a gyalogtisztekéhez hasonló alakban — sötétbarna posztóból, sötétkék béléssel, vállszalag nélkül készült, melyet két sorban elhelyezve öt-öt aranyozott fémgombbal láttak el. A köpeny a boka közepéig ért. ${ }^{47}$ (VI. sz. melléklet)

Az egyenruhát - az orvosokon és a lelkészen kívül — az összes országos büntető intézeti hivatalnok saját költségére volt köteles beszerezni. Az igazgatók a díszöltönnyel és a házi öltönnyel, az ennél alacsonyabb beosztású hivatalnokok háziöltönnyel kellett rendelkezniük. Szolgálatban mindenki köteles volt a házi öltönyt viselni. Mivel a kard az öltözék részét képezte, azt az irodán kívül az intézet egész területén, illetve minden más hivatalos eljárás során kötelező volt viselni. Ünnepélyes alkalmakkor az igazgatók öltözete a díszöltöny volt. Ilyen esetekben — amennyiben beszerezték — a többi

\footnotetext{
* Glosszárium
} 
hivatalnok is, hordhatta a díszöltönyt. Úgy a díszöltöny, mint a házi öltöny, valamint a kard hivatalos eljárás során, illetve az intézeten kívül is hordható volt, de arra senkit nem köteleztek. Az intézeti orvosok számára is megengedett volt az egyenruha viselése, de annak beszerzésére nem kötelezték őket. A lelkészeknek ünnepélyes alkalmakkor saját hivatásszerü öltözékükben kellett megjelenni. Egyenruhát a nyugalmazott hivatalnokok is hordhattak. ${ }^{48}$

Az igazságügyminiszter „A fegyintézetekben alkalmazott fegyőrség és a fegyencek” című rendeletében 1876-ban szabályozta a fegyörök öltözetét. A miniszteri rendelet preambuluma megállapította, hogy a fegyintézeteknél alkalmazott fegyőrség és az ott elhelyezett fegyencek ruházata intézetenként eltérő, ezért ennek az állapotnak a megszüntetésére, az egységesítés bevezetésére van szükség. ${ }^{49}$

A szabályrendelet a fegyőrök számára a barna posztó téli zubbony és mellény helyett a tartósabb színünek bizonyult sötétkék posztóból készült zubbonyt és a búzavirágkék posztóból készült nadrágot rendszeresítette.

A fegyőri öltözékek kihordási idejét az 1873. évi igazságügyminiszteri rendeletben foglaltak alapján határozták meg. ${ }^{50} \mathrm{Az}$ 1876. évi miniszteri rendelet szerint a fegyöri öltözék ruhadarabjainak kihordási ideje volt: a kalap esetében - melyet csak ünnepi alkalmakkor lehetett viselni, egyébként raktárban tárolták — hat év; a köpenyé három év, a posztózubbonyé másfél év, a posztónadrágé egy év, a posztómellényé egy év, a csinvat ${ }^{*}$ zubbonyé két év, a csinvat nadrágé egy év, a posztó sapkáé egy év volt. A rendeletben részletesen szabályozták az egyes ruházati cikkek színét és formáját. ${ }^{51}$

A fegyőri sapka búzavirágkék posztóból készült a honvédségi sapkák mintájára, de bőr szemernyővel.

A köpeny a véderőnél is használt szürke posztóból és fazon szerint készült, a gomblyai félkör alakú rézgombok voltak, a köpenyt pedig csinvat vászonnal bélelték.

A téli zubbony sötétkék posztóból készült 4 centiméter magas álló gallérral, melyet kék szarufa zsinórral ${ }^{*}$ öveztek és vitézkötéssel díszítettek. A téli zubbony a honvédség gyalogsági zubbonyának a mintáját követte. A téli zubbonyt öt darab féldomború rézgombban gombolták be.

A fegyőrök nadrágja magyar szabású volt, melyet búzavirágkék posztóból szabtak. A nadrágot szarufa zsinorzatú vitézkötéssel díszítették.

A mellény eleje búzavirágkék posztóból, a háta pedig fekete pamutkelméből készült, melyet erösebb szürke vászonnal volt béleltek és hét darab csontgombbal láttak el. ${ }^{\mathbf{5 2}}$

A nyári zubbony és nadrág csinvat anyagból készült úgy, hogy az azon lévő hajtóka kivételével már a szabásuk alapján és a gombok alkalmazása által is könnyen megkülönböztethető legyen a fegyencek nyári ruházatától.

Az altiszteknek a fentieken kívül járt egy szőr-kardbojt és évenként egy-egy pár kesztyü. Az egyenruha anyagát, színét, formáját a viselés rendjét az irányító tárca határozta meg, a beszerzésükről azonban a viselőjüknek kellett gondoskodni. Ez alól a kalap jelentett kivételt. A kalapokat egyöntetüségük miatt mindenkor a minisztérium szerezte be.

Az országos letartóztató intézeteknél alkalmazott őrszemélyzet ruházatát megállapító 1876. évi igazságügyminiszteri rendelet az örszemélyzet rangjelvényeit nem határozta meg, ennek következtében az egyes intézetekben eltérő rangjelvényeket viseltek. Az őrszemélyzet rangjelvényeit ezért a miniszter 1893-ban újabb rendelettel szabályozta. Az örparancsnok zubbonyának gallérján ibolyaszínü parolin 3 centiméter széles és 8 centiméter hosszú ezüst paszományt viselt oly módon, hogy a paroli 1 centimét szélességben szabaddá váljon.

$\mathrm{Az}$ őrszemélyzet többi tagjai részére rangjelvényként az ibolyaszínű parolira varrott 1 centiméter széles és 8 centiméter hosszú ezüst paszományok kerültek, amelyeket úgy varrtak fel a zubbony gallérjára, hogy a többsoros paszománynál minden paszomány között 2 milliméter széles hézag maradjon. Közvetítő intézeti főfelügyelő, főfegyőr, börtön őrmester, államfogházi főfelvigyázó pedig három vízszintes paszományt hordott.

Az I. osztályú fegyőr, börtönőr, közvetítő intézeti felügyelő a gallér alsó szélén arányos felosztással két vízszintes paszományt, viselt.

A II. osztályú fegyőr, börtönőr, ugyancsak a gallér alsó szélén egy vízszintes paszományt viselt.

A próbaszolgálatot teljesítő fegyőrök és börtönőrök, addig, amíg végelegesítésük meg nem történt rangjelvényt (rangot) nem viseltek. felelt. $^{53}$

A címzetes őrparancsnok, föfegyőr, stb. azt a rangot volt jogosult viselni, amely a címének meg-

\footnotetext{
* Glosszárium
} 
Az őrparancsnokok, akikre az igazságügyminiszter 1867. évi egyenruharendeletének a hatálya nem terjedt ki másfajta egyenruhát viseltek.

A sapka az intézeti tisztviselőkéhez hasonló alakban, de fekete posztóból készült, melyet ezüst zsinórral és hurkos ezüst rózsával láttak el.

A zubbony az örszemélyzet téli zubbonyához hasonló szabású volt, de a gallér körüli zsinórzat és az ujjakon lévő vitézkötés a kék zsinór helyett domború ezüst zsinórból készült.

A nadrág és a köpeny az intézeti tisztviselők nadrágjához, illetve köpenyéhez hasonló szabású volt és az őrszemélyzet ruházatához használt szövetből készült.

A kard a gyalogsági tiszthelyettesekéhez hasonló hosszú acélkard volt és az igazságügyminiszter 1876. évi egyenruharendeletében meghatározott ezüst kardbojttal volt viselhető. ${ }^{54}$

Az igazságügyminiszter 1893. évi rendeletét 1895-ben újabb rendelettel módosította. Ennek következtében az országos letartóztatási intézetekben alkalmazott őrparancsnokokat és főfelügyelőket az állami tisztviselők XI. fizetési osztályába sorolták, melynek eredményeként a letartóztatási intézetek tisztviselőinek az 1893. évi miniszteri egyenruharendeletben rögzítettek helyett az igazságügyminiszter 1895. évi egyenruharendeletében megállapított egyenruhát kellett viselniük a tiszti írnokok rangjelvényeivel. ${ }^{55}$

A címzetes őrparancsnokok azonban továbbra is az 1893. évi igazságügyminiszteri egyenruharendeletben foglaltak szerinti — az örparancsnok részére megállapított — egyenruhát viselték. ${ }^{\mathbf{5 6}}$

Az 1893-ban az állami tisztviselők, altisztek és szolgák illetményének szabályozásáról és a megyei törvényhatóságok állami javadalmazásának felemeléséről szóló törvény módosította az országos letartóztató intézetek altiszti és őrszemélyzetének a fizetési osztályai szerinti besorolását. ${ }^{57}$

A változás miatt új rangjelvények megállapítására került sor. Ennek rendezése érdekében az igazságügyminiszter 1902-ben elrendelte, hogy az altisztek a keskeny ezüst nyak- és karzsinór mellett:

- az első fizetési osztályban három,

- a második fizetési osztályban két,

- a harmadik fizetési osztályban egy ezüstsávot,

az örök pedig továbbra is a kék nyak- és karzsinór mellett

- az első fizetési osztályban három,

- a második fizetési osztályban ban két,

- a harmadik osztályban egy ezüstsávot viselnek a zubbony hajtókáján. ${ }^{\mathbf{5 8}}$

Az 1928-1829-es költségvetési évtől az országos büntetőintézeteknél, bírósági fogházaknál alkalmazott nőfelügyelők részére egyenruhát rendszeresítettek, amit a nőfelügyelők természetben kaptak meg. Az egyenruha részét alkotta a sapka, köpeny, téli zubbony, téli szoknya, nyári zubbony, nyári szoknya, ing, alsónadrág és cipö. A nők egyenruházatával kapcsolatban ugyanazok a szabályok voltak érvényesek, mint az őrszemélyzet férfi tagjainál, azzal az eltéréssel, hogy a nőfelügyelők az egyenruhát csak szolgálatban voltak kötelesek viselni.

Az igazságügyminiszter 1929. évi rendeletével módosította az országos büntetőintézeti és a bírósági fogházi őrszemélyzet rangjelzéseit.

A rangjelzésként a zubbony gallérjára varrott ibolyaszínü parolin elhelyezett 1 centiméter széles 8 centiméter hosszú ezüstszínü paszomány szolgált.

Ennek megfelelően:

- a fogházőrmester, börtönőrmester és főfegyőr, ezüst nyak és karzsinór mellett a galléron egymástól 2 milliméter távolságra elhelyezett három sávot;

- a fogházőr, börtönőr és fegyőr — akik az I. osztályú altisztek csoportjába tartoztak — kék nyak és karzsinór mellett a gallér alsó szélén arányos elosztással elhelyezett két sávot;

- a fogházör, börtönőr és fegyőr, — akik a II. osztályú altisztek csoportjába tartoztak — kék nyak és karzsinór mellett a gallér alsó szélén elhelyezett egy sávot;

- az ideiglenesen kinevezett közőr pedig a véglegesítéséig rangjelzést nem viselt.

A fogházőrmesteri, börtönőrmesteri, vagy főfegyőri címmel felruházott közőr a címének megfelelö rangjelvényt viselhette.

A nyári zubbonyon nem volt nyak és karzsinór, a fogházőrmester, a börtönőrmester és a főfegyör a hajtóka szélén ezüstszínű zsinórt viselt. ${ }^{59}$

A igazságügyminiszter 1940-ben újabb rendelettel módosította a letartóztató intézeti őrszemélyzet rangjelzéseit. A módosítás a bírósági fogházak és az országos büntetőintézetek őrszemélyzetét érintette. Az ő rangjelvényüket a zubbony gallérjának mindkét végére varrott ibolyaszínủ parolira elhelyezett 1,7 centiméter átmérőjü aranysárga színü fémből készült csillagrózsácska jelölte. 
- Az állami rendszerü II. osztályú altisztek csoportjába tartozó, ideiglenes minőségü letartóztató intézeti öröknek - amíg az őri újonciskola tanfolyamának hallgatói voltak — nem volt rangjelzése.

- A tanfolyam végén a sikeresen vizsgát tett, a II. osztályú altisztek csoportjába tartozó vizsgázott ideiglenes ör rangjelvényként egy csillagrózsácskát viselt.

- A II. osztályú altisztek csoportjába tartozó, a második szolgálati év betöltése után véglegesített ôr két csillagrózsácskát viselt.

- Az állami rendszerű I. osztályú altisztek csoportjába tartozó altisztté kinevezett őr, fogházőr, börtönőr és fegyőr három csillagrózsácskát viselt.

- Az állami rendszerü szakaltisztek csoportjába tartozó főfegyör, börtön őrmester, fogház örmester, ezüst paszomány mellett három csillagrózsácskát viselt.

A búzavirágkék posztóból a honvéd őrmesteri sapka mintájára készült kemény sapkájának alsó széle ibolyaszínű selyemmel átszőtt ezüstzsinórral volt szegélyezve.

A kardbojtja ibolyaszínű fonalakkal átszőtt, csukott ezüst kardbojt.

Az I. osztályú altisztek csoportjába tartozó fogházőr, börtönőr és fegyőr, valamint fogház örmester, börtön őrmester és föfegyőr három évi kifogástalan szolgálat után a zubbony bal alsó ujján egy karsújtást viselt, míg hat évi kifogástalan szolgálat után két karsújtást hordhatott, kilenc évi példamuttató szolgálat után pedig három karsújtást viselhetett. ${ }^{60}$

A fogházőr, börtönőr és fegyőr karsújtása egy centiméter széles, középen kék csíkkal átszőtt, ibolyaszínű selyempaszomány volt. A fogház őrmester, börtön őrmester és főfegyőr karsújtása pedig az előzővel megegyező, de középen ibolyaszínű csíkkal átszőtt ezüstpaszomány volt. Az első karsújtás két vége az ujj végétől tizenegy centiméterre esett és innen a vitézkötést ívszerüen övezve ennek a csúcsától fél centiméterre, három centiméter hosszú és két egész háromtized centiméter széles karikában végződött. Ha több karsújtást kellett felvarrni, mindegyik között egy centiméternyi közt kellett hagyni és mindig csak a legfelső sújtás végződött karikában, a többi karsújtás karika nélküli ívben övezte a vitézkötést.

Az I. osztályú altisztek csoportjába tartozó és fogház őrmesteri, börtön őrmesteri és főfegyőri címmel felruházott fogházőrt, börtönőrt és fegyőrt a címének megfelelő rangjelzés illette meg, karsújtást azonban nem viselhetett.

A nyári zubbonyon nem volt nyak- és karzsinór, csak a fogház örmester, a börtön örmester és a föfegyör hajtókájának szélén volt három milliméter széles, lapos ezüstzsinór.

A nőfelügyelők egyenruháján rangjelvény nem volt. ${ }^{61}$

Összességében megállapítható, hogy a polgári magyar állam büntetés-végrehajtási szervezetében foglalkoztatottak egyenruházata jól szolgálta feladataik eredményes végrehajtását. Az egyenruha kifejezte viselöjének a hierarchiában betöltött helyét és szerepét, a testülethez, illetve a magyar államhoz való tartozását. Emellett pedig követte a korabeli egyenruhadivatot, nevezetesen a honvédség egyenruhaszabását. A büntetés-végrehajtási testület rangrendszere illeszkedett a magyar állam különböző alrendszereiben kialakított őrtestületek rendfokozati rendszereibe egyben pedig kifejezte a büntetésvégrehajtási testület sajátosságait. Az is egyértelmü, hogy a rendfokozatok — illetve korabeli szóhasználat szerint a kitűntetési jelek, vagy rangjelvények — nem csupán önmagukban jelölték viselőjük rangját. Az egyenruha anyaga, szabása és díszítettsége is hathatós eszköze volt a viselője társadalmi állása érzékeltetésének. Az állami alkalmazotti lét biztos egzisztenciát jelentett, ami egyrészt lehetővé tette a személyi állomány színvonalorientált kiválasztását és a müködés szakmai színvonalának magas szinten tartását. E helyzet következményeként pedig a személyi állomány társadalmi megítélése - a társ állami rendvédelmi testületekhez hasonlóan — kedvező volt. A polgári magyar állam időszakában a büntetés-végrehajtási személyzet — a társ szervezetek tagjaihoz hasonlóan — szívesen viselte egyenruháját, büszke volt a testületi rangjaira.

\footnotetext{
Jegyzetek:

${ }^{1}$ EsTóK: A büntetés-végrehajtás függelmi viszonyrendszerének, felügyeletének története 1867-1990. 31.p.

² Zemplén vármegyében a várnagy, a hajdúk feladatait a ,Várnagy instrukciója” a „,Hajdúk regulamentuma”, míg a rabokra vonatkozó szabályokat „A börtönélet rendszabásai” tartalmazták.

${ }^{3}$ VAJNA: I.köt. 1-43.p.

${ }^{4}$ „, . . egy legénynek csizmára 12 frt. $10 \mathrm{kr.t}$, ruhára pedig 14 frt. $36 \mathrm{kr}$-t költöttek. , ,...amely áll kaput-rokkból, ${ }^{*}$ mellényböl, nadrágból és csákóból."

Loc.cit. I.köt. 104.p.
}

* Glosszárium 
${ }^{5}$ EsтóK: A büntetés-végrehajtás függelmi viszonyrendszerének, felügyeletének története 1867-1890. op.cit. 31.p. ; KABODI - LÖRINCZ - MEZEY: 127.p.

${ }^{6}$ EsTóK: A büntetés-végrehajtás függelmi viszonyrendszerének, felügyeletének története 1867-1990. 32.p.

${ }^{7}$ Loc.cit.

${ }^{8}$ MEGYeRY: 37-38.p.

920 172/1863. (VII. 10.) HT.r.

Loc.cit.

${ }^{10}$ MEGYERY István föügyészhelyettesnek — a magyar börtönügyet bemutató műve — a munkácsi fegyintézettel kapcsolatosan közölt 1857. évi statisztikai adataiban szerepel: „Az örségi személyzet állott: 1 örparancsnokból 350 frt. 6 föfegyörböl, 240 frt, 60 fegyörböl 180 frt. évi zsolddal teljes egyen ruházattal és naponkénti kenyér illetménnyel díjazva. Az örparancsnoknak ezen kívül szabad lakása, öt öl tüzifája és 36 font gyertyából álló természetbeni illetménye volt. Az intézet biztonsága érdekében a várban tartózkodó katonai örizet állott: 1 káplár, 1 szakaszvezetö, 2 kürtös és 40 közemberböl. Ezek évi pótilletéke kitett: 3899 frt. 67 krt."

MEGYERY: op.cit.

1120 172/1863. (VII. 10.) HT.r. op.cit.

12 Lipótváron KovÁch Ernő volt 1848-as őrnagy, Illaván ZÁmBELly Lajos volt 1848-as honvéd huszár ezredes, Nagyenyeden INCZÉDY László volt 1848-as honvéd ezredes, Szamosújváron BoÉR János volt 1848-as honvédtiszt kapott igazgatói kinevezést. A fentieken kívül ügyészek, ügyvédek kerültek felelős büntetés-végrehajtási beosztásokba. Feltételezhető, hogy ők a 1848-as honvédségi egyenruhát viselték.

13 „,... a fegyörök egyenruhát kapnak, amit folyamatosan viselnek, a nöfelügyelök saját költségükön szereznek be egyszerü sötét-szürke öltönyt, amit csak szolgálatba viselnek.”

${ }^{14}$ GALÁNTAI: 9-95.p.

$151867 /$ XII.tc.

${ }^{16}$ MeZeY: A magyar polgári börtönügy kezdetei.

${ }^{17}$ Idem: A polgári börtönügyi tudományosság a XIX-XX. század Magyarországán.

${ }^{18}$ PULSZKY - TAUFER

${ }^{19}$ PARÁDI: A polgári magyar állam rendvédelmi testületeinek humán viszonyai 1867-1945.

${ }^{20}$ Idem: Rendvédelmi tisztképzésünk hagyományai.

${ }^{21}$ Idem: Rendvédelmünk képzési és képesítési rendszere 1867-1945.

${ }^{22}$ Idem: A magyar rendvédelem személyi állományának szociális viszonyai 1867-1945.

${ }^{23}$ Loc.cit.

${ }^{24}$ OLASZ - PARÁDI - ZEIDLER

${ }^{25}$ ZEIDLER: 95.p. + 9.p.

${ }^{26}$ PARÁDI: A katonailag szervezett őrtestület és a polgári őrtestület.

${ }^{27}$ Idem: Az egységes állami fizetési rendszer és a szakterületi rendfokozati rendszerek a polgári magyar állam rendvédelmében.

${ }^{28}$ MEGYeRY: op.cit. 296.p.

${ }^{29}$ A 9 863/1895.IM. rendeletet egységesítették a 43 845/1891.IM. rendelettel, így a mindennapi használat során az 1891. évi rendeletszámot és címet használták.

43 845/1891. (XI. 30.) IM.r.

${ }^{30}$ A fizetési osztályok rendszerét törvényi úton több ízben szabályozták.

1873/II.tc. ; 1883/I.tc. ; 1893/IV.tc.

${ }^{31} \mathrm{Az} 1891$. évi rendeletét az igazságügyi miniszter 1895-ben egy újabb rendeletével módosította.

43 845/1891. (XI. 30.) IM.r.

${ }^{32}$ Loc.cit.

${ }^{33}$ Loc.cit.

${ }^{34}$ SZÖLLÖSY: 389-390.p.

${ }^{35}$ Loc.cit.

3643 845/1891. (XI. 30.) IM.r.op.cit.

${ }^{37}$ Loc.cit.

${ }^{38}$ SZÖLLÖSY: op.cit. 389-390.p.

${ }^{39} 43$ 845/1891. (XI. 30.) IM.r.op.cit.

${ }^{40}$ Loc.cit.

41 1893/IV.tc. op.cit. 17. §

4243 845/1891. (XI. 30.) IM.r.op.cit.

${ }^{43}$ Loc.cit.

${ }^{44}$ Loc.cit.

${ }^{45}$ Loc.cit.

${ }^{46}$ Loc.cit.

${ }^{47}$ Loc.cit.

${ }^{48}$ Loc.cit.

4932 420/1876. (XI. 15.) IM.r.

5012 951/1873. (X. 26.) IM.r.

5132 420/1876. (XI. 15.) IM.r. op.cit.

526 980/1893. (III. 22.) IM.r.

${ }^{53}$ Loc.cit.

${ }^{54} 32$ 420/1876. (XI. 15.) IM.r. op.cit.

556 980/1893. (III. 22.) IM.r. op.cit.

${ }^{56}$ Loc.cit. 
57 1893/IV.tc. op.cit.

5823 319/1902. (III. 26.) IM.r.

5911 599/1929. (IV. 17.) IM.r.

${ }^{60}$ Loc.cit.

${ }^{61} 11$ 599/1929. (IV. 17.) IM.r. op.cit. ； 37 600/1940. (VI. 26.) IM.r.

Jegyzetekben alkalmazott röviditések:

\section{MONOGRÁFIÁK KISMONOGRÁFIÁK ÉS HASONLÓ JELLEGÜ KÖTETEK}
Galántai — Galántai József: A Habsburg-monarchia alkonya. Osztrák-magyar (14.;) dualizmus 1867-1918. Budapest, 1985, Kossuth Kiadó. 386 p. HU- ISBN 9630925893.

MEGYERY

$(8 . ; 10 . ; 28 . ;)$

- MEgYeRY István: A magyar börtönügy és az országos letartóztatási intézetek. Budapest, 1905, Magyar Királyi Igazságügyminisztérium. 572 p.

MEZEY: A magyar polgári börtönügy kezdetei.

(16;)

MEZEY Barna: A magyar polgári börtönügy kezdetei. Budapest, 1995, Osiris. 230 p. HU-ISBN 963838488 3. /Jogtörténeti Értekezések./ HUISSN 0134-0026.

PULSZKY - TAUFFER

(18.;)

PULSZKY Ágost — TAUfFER Emil: A börtönügy múltja, elmélete, jelen állás, különös tekintettel Magyarországra. Pest, 1867, Emich Gusztáv. 325 p.

SZÖLLŐSY

(34.;35.;38.;)

- SzÖLLÖSY Oszkár: Magyar Börtönügy. Büntetések és biztonsági intézkedések végrehajtása. Budapest, 1935², Révai Testvérek Irodalmi Intézet. Rt. 608 p.

VAJNA

$(3 . ; 4 . ;)$

— VAjNA Károly: Hazai régi büntetések. I-II. kötet. Budapest, 1906-1907. VAJNA Károly. 1277 p.

\section{TANULMÁNYOK}

EsTÓK

$(1 . ; 5 ; 6 . ; 7 . ;)$
- EsTóK József: A büntetés-végrehajtás függelmi viszonyrendszerének, felügyeletének története 1867-1990 között. Börtönügyi Szemle, XXXII.évf. (2013) 4.sz. 28-54.p. HU-ISSN 1417-4758.

MEZEY: A polgári börtönügyi tudományosság a XIX-XX. század Magyarországán.

$(17 . ;)$

OLASZ - PARÁDI - ZEIDLER (24.;)

MEZEY Barna: A polgári börtönügyi tudományosság a XIX-XX. század Magyarországán. In BeliznAy Kinga - Mezey Barna (szerk.): A magyar börtönügy kutatásának alapjai. Budapest, 2000², ELTE-ÁJK. 199 p. HU-ISBN 963463221 1. /Jogtörténeti értekezések, 20./ HUISSN 0134-0026.

OlASz György — PARÁDI József — ZEIDLER Sándor: A magyar állami rendvédelmi testületek katonai rendfokozati rendszerei a kiegyezéstöl az ezredfordulóig. Rendvédelem-történeti Füzetek (Acta Historiae Praesidii Ordinis), XV.évf. (2008) 18.sz. 29-35.p. HU-ISSN 12166774. A tanulmány korábbi változata 2004. október 13-án Budapesten hangzott el a Szemere Bertalan Magyar Rendvédelem-történeti Tudományos Társaság által szervezett rendvédelem-történeti tudományos konferenciasorozatnak „Karhatalmi feladatok a bünmegelözés és a békefenntartás szolgálatában Európában a XIX-XX. században" című XVIII. konferenciáján. A publikált tanulmány az előadás javított, bővített és átdolgozott változata.

PARÁDI: Rendvédelmi tisztképzé- — PARÁDI József: Rendvédelmi tisztképzésünk hagyományai. Rendészesünk hagyományai.

(20.;) ti Szemle, XXX.évf. (1997) 4.sz. 101-109.p. HU-ISSN 1218-8956.

PARÁDI József: Rendvédelmünk képzési és képesítési rendszere 1867-1945. Rendvédelem-történeti Füzetek (Acta Historiae Praesidii Ordinis), XIII.évf. (2007) 16.sz. 90-93.p. HU-ISSN 1216-6774. és képesítési rendszere 1867-1945.

(21.;) 
PARÁDI: A magyar rendvédelem személyi állományának szociális viszonyai 1867-1945.

(22.;23.;)

PARÁDI: A polgári magyar állam rendvédelmi testületeinek humán viszonyai 1867-1945.

PARÁDI: Az egységes állami fizetési rendszer és a szakterületi rendfokozati rendszerek a polgári magyar állam rendvédelmében. (27.;)

PARÁdI: A katonailag szervezett őrtestület és a polgári őrtestület. (26.;)

ZEIDLER

\section{JOGSZABÁLYOK}

1867/XII.tc.

1873/II.tc.

1883/I.tc

(30.;)

1893/IV.tc.

(30.;41.;57.;)

20 172/1863. (VII. 10.) HT.r. (9.;11.;)

12 951/1873. (X. 26.) IM.r. (50.;)

32 420/1876. (XI. 15.) IM.r. $(49 . ; 51 . ; 54 . ;)$
PARÁDI József: A magyar rendvédelem személyi állományának szociális viszonyai 1867-1945. Rendvédelem-történeti Füzetek (Acta Historiae Praesidii Ordinis), XIV.évf. (2008) 17.sz. 57-64.p. HU-ISSN 1216-6774.

PARÁDI József: A polgári magyar állam rendvédelmi testületeinek humán viszonyai 1867-1945. Rendvédelem-történeti Füzetek (Acta Historiae Praesidii Ordinis), XX.évf. (2010) 22.sz. 92-114.p. HU-ISSN 1216-6774.

PARÁDI József: Az egységes állami fizetési rendszer és a szakterületi rendfokozati rendszerek a polgári magyar állam rendvédelmében. Rendvédelem-történeti Füzetek (Acta Historiae Praesidii Ordinis), XXII.évf. (2012) 26.sz. 105-119.p. HU-ISSN 1216-6774. A tanulmány korábbi változata 2011. november 11-én, Budapesten hangzott el, a Szemere Bertalan Magyar Rendvédelem-történeti Tudományos Társaság által szervezett rendvédelem-történeti tudományos konferenciasorozatnak ,Militarizmus és demilitarizmus a XIX-XX. századi magyar állam rendvédelmében" című XXV. konferenciáján. A publikált tanulmány az előadás javított, bővített és átdolgozott változata.

PARÁDI József: A katonailag szervezett őrtestület és a polgári őrtestület. Rendvédelem-történeti Füzetek (Acta Historiae Praesidii Ordinis), XXV.évf. (2015) 43-44-45-46.sz. 77-84.p. HU-ISSN 1216-6774.

- ZEIDLER Sándor: A testőrségi rendfokozatok a polgári magyar állam időszakában. Rendvédelem-történeti Füzetek (Acta Historiae Praesidii Ordinis), XXV.évf. (2015) 47-48-49-50.sz. 95-101.p. HU-ISSN 12166774.

— 1867/XII.tc. a Magyar Korona országai és az Ö Felsége uralkodása alatt álló többi országok között fennforgó közös érdekű viszonyokról, s ezek elintézésének módjáról.

- 1873/II.tc. a kiszolgált altisztek alkalmazásáról.

— $\quad$ 1883/I.tc. a köztisztviselők minősítéséről.

1893/IV.tc. az állami tisztviselők, altisztek és szolgák illetményeinek szabályozásáról, és a megyei törvényhatóságok állami javadalmazásának felemeléséröl.

20 172/1863. (VII. 10.) HT.r. a hatósági fogházak szervezetéröl.

MEGYERY István: A magyar börtönügy és az országos letartóztatási intézetek. 37-38.p. Budapest, 1905, Magyar Királyi Igazságügyminisztérium. 572 p.

- 12 951/1873. (X. 26.) IM.r. a fegyörök ruhailletménye és az egyes ruhanemük hordideje. VI.köt. 185-187.p.

In MARSCHALKÓ János (szerk.): A hatályban lévö igazságügyminiszteri rendeletek rendszeres gyüjteménye.

- I.köt. Az igazságszolgáltatás közegei. 753 p. 1896.

- II.köt. Polgári perrendtartás, kereskedelmi váltó- és csődeljárás, végrehajtás, telekkönyv. 768 p. 1896.

- III.köt. Birtokrendezés, bányajogok, családjog, örökösödési eljárás, határörvidék és Fiume. 651 p. 1896.

- IV.köt. Büntetöjog és eljárás, jogsegély. 582 p. 1896.

- V.köt. Ügyvitel, gazdasági ügyek. 801 p. 1897.

- VI.köt. Büntetések végrehajtása, tartalommutatók. 801 p. 1897.

- VII.köt. 1326 p. 1902.

- VIII.köt. 612 p. 1909.

- IX.köt. 826 p. 1909.

Budapest, Grill Károly.

32 420/1876. (XI. 15.) IM.r. a fegyintézetben alkalmazott fegyőrség és fegyencek. VI.köt. 185-187.p.

In MARSCHALKÓ János (szerk.): A hatályban lévő igazságügyminiszteri 
43 845/1891. (XI. 30.) IM.r. $(29 . ; 31 . ; 32 . ; 33 . ; 36 . ; 37 . ; 39 . ; 40 . ;$ 42.;43.;44.;45.;46.;47.;48.;)

6 980/1893. (III. 22.) IM.r. (52.;53.;55.;56.;)

23 319/1902. (III. 26.) IM.r. (58.;)

11 599/1929. (IV. 17.) IM.r. (59.;60.;61.;)

37 600/1940. (VI. 26.) IM.r. (61.;) rendeletek rendszeres gyüjteménye.

- I.köt. Az igazságszolgáltatás közegei. 753 p. 1896.

- II.köt. Polgári perrendtartás, kereskedelmi váltó- és csődeljárás, végrehajtás, telekkönyv. 768 p. 1896.

- III.köt. Birtokrendezés, bányajogok, családjog, örökösödési eljárás, határörvidék és Fiume. 651 p. 1896.

- IV.köt. Büntetőjog és eljárás, jogsegély. 582 p. 1896.

- V.köt. Ügyvitel, gazdasági ügyek. 801 p. 1897.

- VI.köt. Büntetések végrehajtása, tartalommutatók. 801 p. 1897.

- VII.köt. 1326 p. 1902.

- VIII.köt. 612 p. 1909.

- IX.köt. 826 p. 1909.

Budapest, Grill Károly.

- 43 845/1891. (XI. 30.) IM.r. öltözeti szabályzat az országos büntetőintézeti hivatalnokok részére. VI.köt. 191-199.p.

In MARSCHALKó János (szerk.): A hatályban lévő igazságügyminiszteri rendeletek rendszeres gyüjteménye.

- I.köt. Az igazságszolgáltatás közegei. 753 p. 1896.

- II.köt. Polgári perrendtartás, kereskedelmi váltó- és csődeljárás, végrehajtás, telekkönyv. 768 p. 1896.

- III.köt. Birtokrendezés, bányajogok, családjog, örökösödési eljárás, határôrvidék és Fiume. 651 p. 1896.

- IV.köt. Büntetöjog és eljárás, jogsegély. 582 p. 1896.

- V.köt. Ügyvitel, gazdasági ügyek. 801 p. 1897.

- VI.köt. Büntetések végrehajtása, tartalommutatók. 801 p. 1897.

- VII.köt. 1326 p. 1902.

- VIII.köt. 612 p. 1909.

- IX.köt. 826 p. 1909.

Budapest, Grill Károly.

- $6980 / 1893$. (III. 22.) IM.r. az országos büntető intézetek őrszemélyzeti rangjelvényeinek és az örparancsnokok egyes ruházatának megállapítása tárgyában. VI.köt. 191-199.p.

In MARSCHALKó János (szerk.): A hatályban lévő igazságügyminiszteri rendeletek rendszeres gyüjteménye.

- I.köt. Az igazságszolgáltatás közegei. 753 p. 1896.

- II.köt. Polgári perrendtartás, kereskedelmi váltó- és csődeljárás, végrehajtás, telekkönyv. 768 p. 1896.

- III.köt. Birtokrendezés, bányajogok, családjog, örökösödési eljárás, határörvidék és Fiume. 651 p. 1896.

- IV.köt. Büntetőjog és eljárás, jogsegély. 582 p. 1896.

- V.köt. Ügyvitel, gazdasági ügyek. 801 p. 1897.

- VI.köt. Büntetések végrehajtása, tartalommutatók. 801 p. 1897.

- VII.köt. 1326 p. 1902.

- VIII.köt. 612 p. 1909.

- IX.köt. 826 p. 1909.

Budapest, Grill Károly.

- 23 319/1902. (III. 26.) IM.r. az országos letartóztatási intézetekben alkalmazott őrök és altisztek rangjelzésének megállapítása tárgyában. Igazságügyi Közlöny, XI.évf. (1902) 4.sz. 112-113.p.

- $\quad 11$ 599/1929. (IV. 17.) IM.r. az országos büntetőintézeti és a bírósági fogházi őrszemélyzet rangjelzéseinek megállapítása tárgyában. Igazságügyi Közlöny, XXXVIII. (1929) 4.sz. 61.p.

- 37 600/1940. (VI. 26.) IM.r. letartóztató intézeti őrszemélyzet rangjelzésének megállapítása tárgyában. Igazságügyi Közlöny, XLIX. (1940) 6.sz. 137-138.p. 


\section{Glosszárium:}

atilla $\quad=\quad$ Az atilla eredetileg rövid díszes zsinóros kabát, a hunok királyáról, Attiláról elnevezett ruhadarab, a magyar úri viselet része. Az atilla a lovas ruhából alakult ki. A bocskaitól a zsinórzatában különbözik. Oldalvonala karcsúsított, az alja kiszélesedik, a derékvonalig szűk utána „szoknyásan” bővül, ami megkönnyítette a lóról való le- és felszállást. A sújtás mellett vitézkötés díszítette. Később katonai ünnepi viselet is lett. Az 1830-as években alakult ki, miután a XVIII. század végén a magyaros ruha kezdett eltűnni. II. József azonban a németet tette meg hivatalos nyelvnek, mire válaszul a magyar nemesség visszatért a nemzeti viselet elemeihez. A Bach-rendszer idején tiltották a magyaros öltözéket, ezért a bálokon sokan tiltakozásként viselték az atillát és más magyar ruhadarabokat, majd divattá vált a magyar ruha viselése.

boglár $\quad=\quad$ Ötvösmunkával díszített gomb, csat vagy más ékítmény, ékszer, amelyet díszruhán,

övön viselnek, és arany vagy ezüstfonallal szövik át.

bürü csatt $\quad=\quad$ keskeny csatt

csinvat $\quad=\quad \underline{\text { sávolykötésủ szövetek gyüjtöneve. }}$

merinó $\quad=\quad$ Mivel a merinói szálakból készült szövet külseje zömmel hidrofób (föleg a kezelt anyagoké), belsejük pedig hidrofil (15-30\%), ezért bár a szálak sok nedvességet vesznek fel, azt mégis magukban tartják, nem pedig pamut-módjára a felületükön. Emiatt száraz érzést adnak.

nemez $\quad=\quad$ Ösi eredetü textil, amit hagyományosan birkagyapjúból gyúrnak vizes közegben.

nyakravaló $\quad=\quad$ A nyakravaló önálló ing gallér amelynek a formai kialakítása a teljes állomány részére megegyezett, de anyagában különbözött. A tiszti állomány részére fekete selyemből vagy gyapjúszövetből, a legénység részére gyapjúszövetből készült. A nyakravalóra belülről fehér nyakszalagot varrtak, melyből a nyakravalóra visszahajtva 3 mm széles nyakszegélyt képezett.

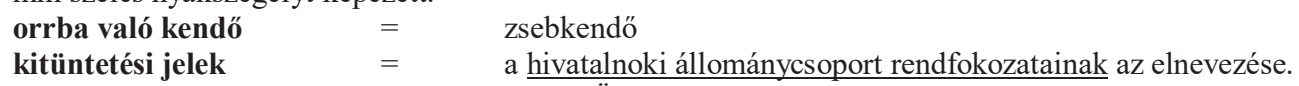

A kifejezést elöször 43 845/1891. (XI. 30.) „Öltözeti szabályzat a magyar kir. országos büntető intézeti hivatalnokok részére” címü igazságügyminiszteri rendeletben használták.

paroli $\quad=\quad$ az egyenruha hajtókáján alkalmazott változó alakú és színü jelzés amely a viselőjének a testületi hovatartozását jelölte. Abban az időben, maikor az egyenruha fazonján viselték a rendfokozatot a rendfokozati jeleket a parolin helyezték el.

paszomány $\quad=\quad$ (régiesen paszománt): arany-, ezüst- vagy selyemszálakból készített lapos szalag, zsinór, amelyeket díszítésül vartak fel viseletekre.

rangjelzés $\quad=\quad$ az örszemélyzeti állománycsoport rendfokozatainak az elnevezése

A kifejezést elöször 6980/1890. (III. 22.) „Az országos büntetö intézetek őrszemélyzete rangjelvényeinek és az őrparancsnokok egyenruházatának megállapitásáról " címủ igazságügyminiszteri rendeletben használták.

rugony $\quad=\quad$ rugony nevü műnek azon szára, mely a nyomásnak rugódása. Vasból, vagy rézből, melyekkel a lábbeli sark alá varrott bőrszeleteket megerősítik.

$\begin{array}{lll}\text { szarufa zsinór } & = & \text { kék selyemfonalból kötött díszítő zsinórzat. } \\ \text { szattyánbőr } & = & \text { puhára cserzett, élénk színüre festett borjú-, juh- v. kecskebör. }\end{array}$

szájkarika $\quad=\quad$ A kardhüvely felső nyílásába a szájkarika van beillesztve, amelynek a hüvelybe lenyúló és rugalmas két nyelve a kardnak a hüvelyben való megtartására szolgál. A szájkarikát a hüvelyben a két oldalról bedugott csavar tartja meg.

verítékbőr $=$ a férfikalapok belső peremén körbefutó börcsík. E bőrcsík rendeltetése, hogy ne engedje át az izzadságot és ezáltal a kalap ne zsírosodjon át (ellenkező célú a sisak verítékbőr). Juh-, bárány-, kecskebőrből készül. Ideális esetben növényi cserzéssel, de krómos, krómos-növényi cserzéssel is, kollódiumos kikészítéssel készül.

vitézkötés = magyar eredetű zsinór anyagú mintázat, melyet az egyenruha nadráhján, zubbonyán és a fejfedőn egyaránt alkalmaztak. A vitézkötés díszessége a viselt rendfokozattal együtt növekedett.

\section{Mellékletek jegyzéke:}

I.sz.melléklet

A csillag, csillagrózsácska és a rozetta.

II.sz. melléklet

Paszomány mintázatok.

III.sz. melléklet

Az országos büntető intézetek hivatalnokainak egyenruhája.

IV.sz. melléklet

Az attila, zubbony és nadrág, valamint hím- és nőkapocs.

V.sz. melléklet

Az büntetés-végrehajtási egyenruhához rendszeresített szablya és hordszíja.

VI.sz. melléklet

A köpeny. 
A csillag, csillagrózsácska és a rozetta.

I.sz.melléklet

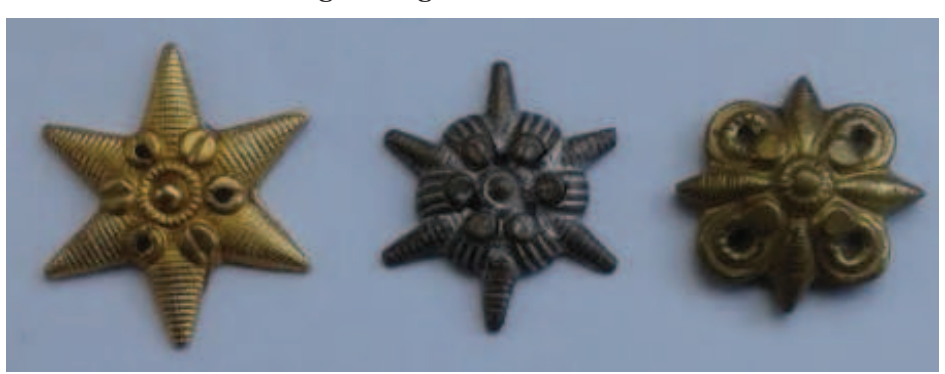

Forrás ! ZeIDLER Sándor magángyüjteménye.

\section{Paszomány mintázatok.}

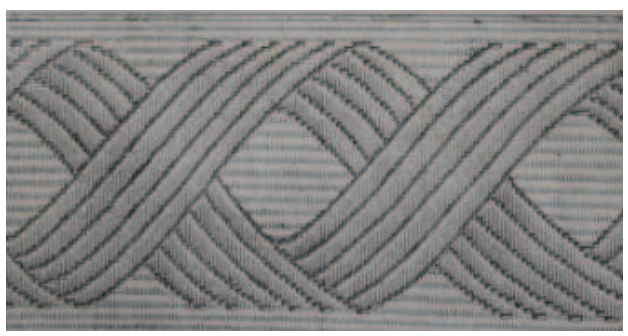

Megjegyzés: Tisztviselői állományúak részére.

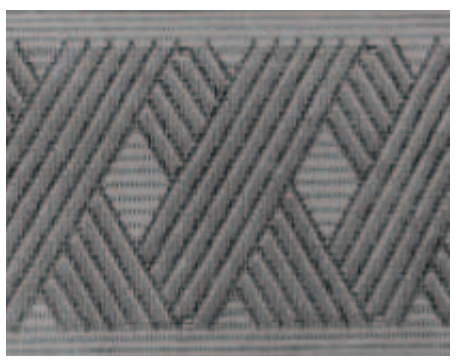

Megjegyzés: Katonai tiszttviselői állományúak részére.

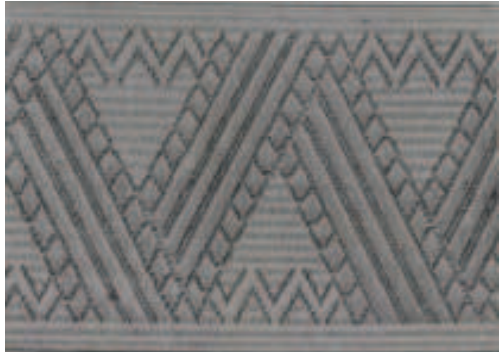

Katonai állományúak részére.

Forrás ! Öltözeti és felszerelési szabályzat a Magyar Királyi Honvédség számára. Budapest, 1911, Pallas. 131 p. Paszományok 17-18.p.

Az országos büntető intézetek hivatalnokainak egyenruhája.

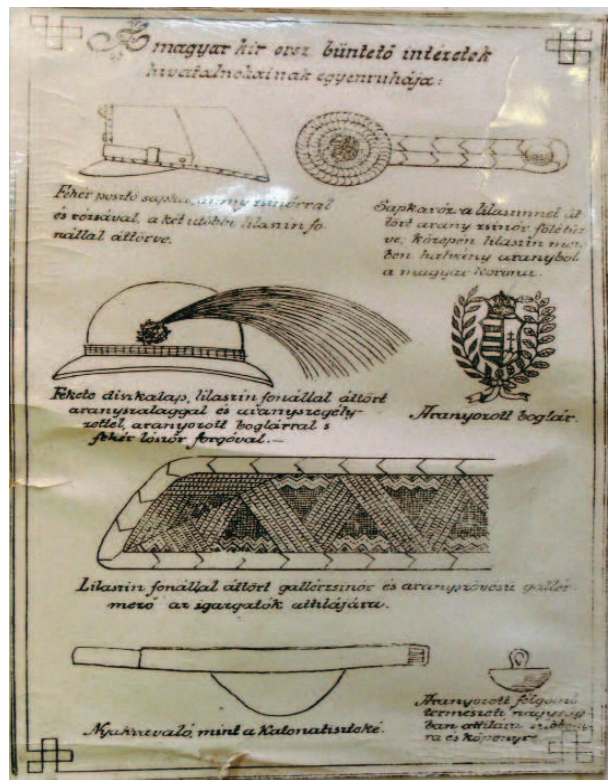

Forrás ! A szerző magángyüjteménye 
Az attila, zubbony és nadrág, valamint hím-és nőkapocs.
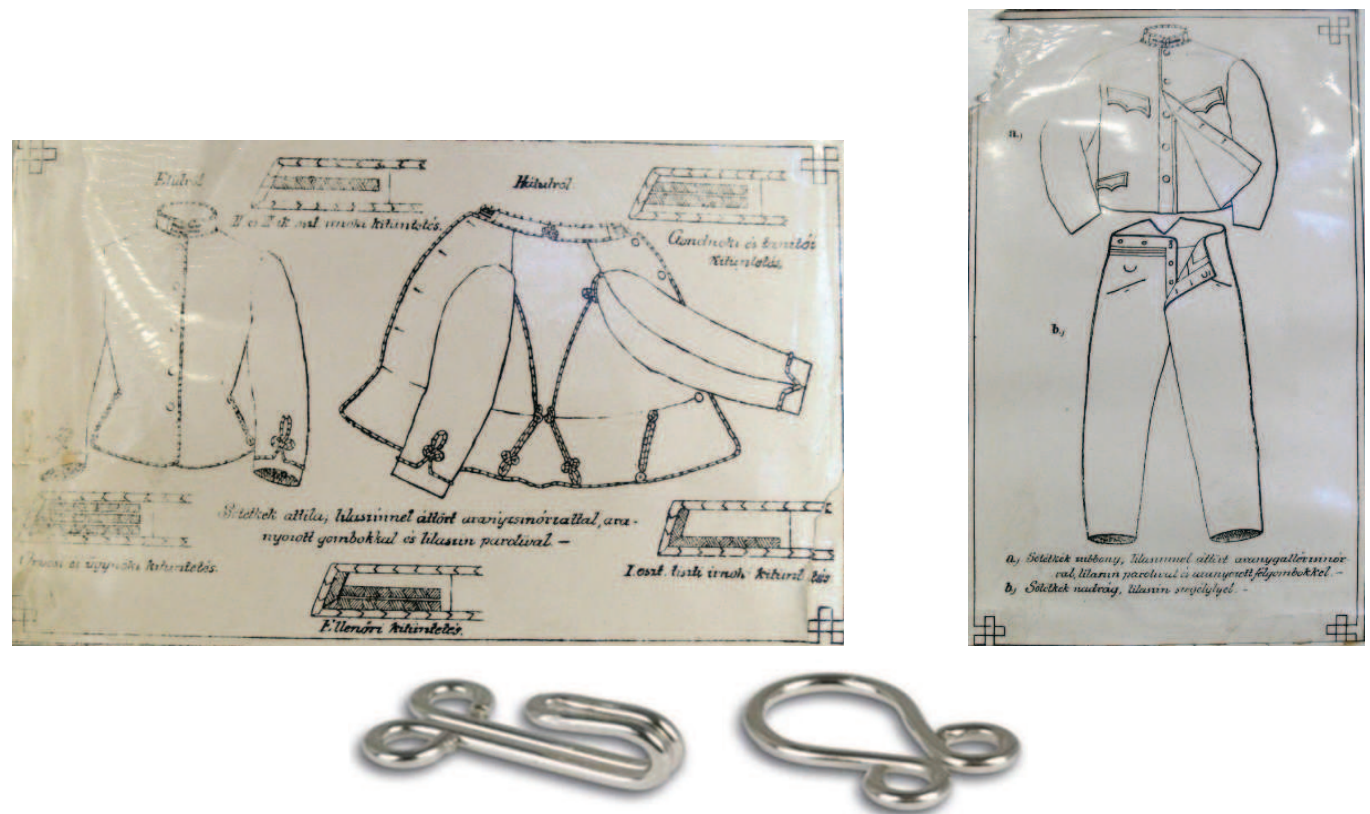

Forrás ! A szerző magángyüjteménye

Az büntetés-végrehajtási egyenruhához rendszeresitett szablya és hordszija.

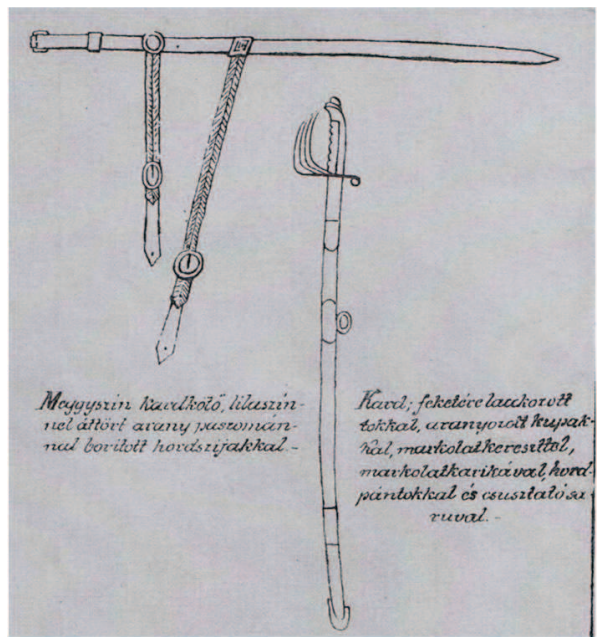

Forrás ! A szerző magángyüjteménye

A köpeny.

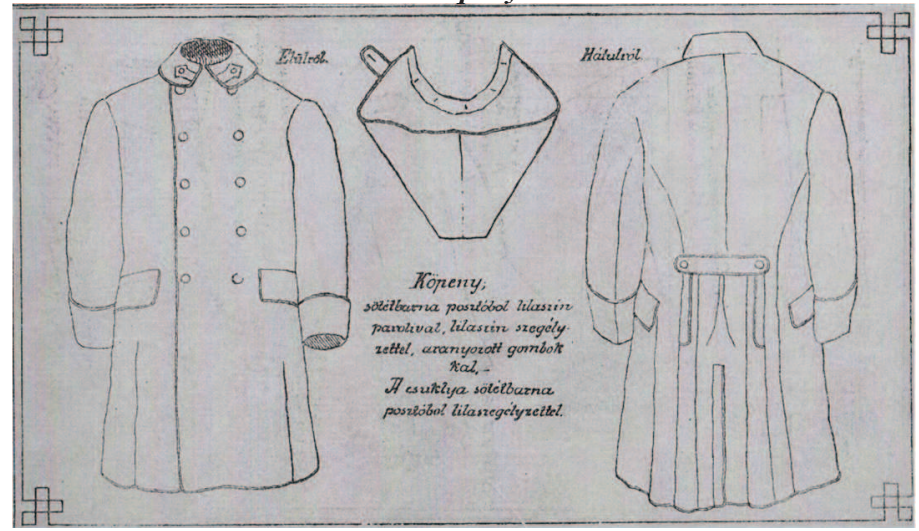

Forrás ! A szerző magángyüjteménye 